\title{
Reflektoiva ammattikäytäntö ja sen oppiminen
}

Schön, Donald, Educating the Reflective Practitioner. Jossey-Bass Publishers. London. 1987.

Schön jatkaa edellisen teoksensa (The Reflective Practitioner, 1983) teemaa länsimaisen asiantuntijatyön kriisistä. Uuden teoksen toinen pääkysymys on teknis-rationaalisen asiantuntijakoulutuksen kritiikki ja toinen reflektoivaan ammattikäytäntöön johtavan koulutusajattelun ja oppimistapojen hahmottelu. Schön haluaa kritiikin lisäksi tuoda konkreettisia kehittämisen vaihtoehtoja. Teos on tarkoitettu käytännön asiantuntijoille, korkeakoulujen opettajille ja opiskelijoille sekä opetushallinnon virkamiehille korkeakoulutasoisen ammatillisen (professional) koulutuksen kehittämisen käynnistäjäksi.

Kirjan lähtökohtana on väite, että ammatillinen (professional) opetus on yhä kauempana siitä todellisuudesta, jonka edessä asiantuntijat tämän hetken yhteiskunnassa ovat. Koulutuksen perustana oleva tiede ja tieteellinen tutkimus on etääntynyt yhä kauemmaksi todellisuudesta. Esimerkkinä Schön mainitsee mm. johtamisen, johon kohdistuvalla tieteellisellä tutkimuksella on yhä vähemmän tekemistä johtamistyön kehittämisessä.

\section{Teknis-rationaalisen asiantun- tijatyön kriisiytyminen}

Schön kertaa edellisessä teoksessa (1983) esittämänsä teknis-rationaalisen asiantuntijatyön kritiikin: Länsimainen asiantuntijatoiminta on muodostunut instrumentaaliseksi ongelmanratkaisutoiminnaksi, jonka tehtävänä on valita vain teknisesti parhaiten sopivimmat, tutkimusfaktoin perustellut keinot valmiiksi rajattujen ongelmien ratkaisuun. Todellisuus ei kuitenkaan ole kapea-alainen erillisongelma. Todellisuus sisältää epävarmuutta, ainutkertaisuutta ja arvoristiriitoja, joiden ratkaisut eivät ole mahdollisia teknisrationaalisen asiantuntemuksen yhä pirstoutuvamman tietopohjan perusteella. Schönin mukaan eri alueiden asiantuntijatyön kriiseihin teknis-rationaalisen profession vastausyrityksinä on ollut mm. asiantuntemuksen monopolisointi ja oman asiantuntemusalueen mystifiointi sekä valittelut siitä, että oman asiantuntemusalueen kriisit ja ongelmat johtuvat vain ammattikunnan vaikutusmahdollisuuksien ja vallan vähäisyydestä (suomalaisessa professionaalisessa keskustelussa esim. virkojen ja muiden resurssien vähäisyyden valitteluna/KL). Schönin mukaan nämä vaatimukset ja puolustelut eivät ratkaise työn kehittämisvaatimusten todellisia ongelmia.
Tieteellisen tiedon asema ammatillisen koulutuksen perustana

Schön toteaa, että nykyisten tutkimusyliopistojen koulutus perustuu teknis-rationaalisen asiantuntijanäkemyksen arvomaailmaan. Koulutuksen alku on perinteisen tieteenkäsityksen mukainen perustiede, sen jälkeen ns. relevantti sovellettu tieto ja sitten käytäntö. Näin esimerkiksi lääkäreistä koulutetaan biotieteiden kapea-alaisia teknisiä ongelmanratkaisijoita, joilla ei ole mahdollisuutta toimia todellisina asiantuntijoina yhteiskunnan terveydenhuollon yhä monimutkaisemmiksi käyvissä kysymyksissä. Tieteellinen tieto toimii ennenkaikkea määritettäessä professioiden asemaa toistensa suhteen. Oletus, että nykyinen akateeminen tutkimus tuottaa hyödyllistä tieteellistä tietoa todellisuuden ongelmien ratkaisemiseksi ja ammattikäytännön kehittämiseksi alkaa Schönin mielestä käydä yhä kyseenalaisemmaksi.

Ammatillinen tieto nähdään tieteen välineellisenä sovellutuksena, tiede ja tutkimus luo uutta ja käytäntö "vain" soveltaa. Tosiasiassa juuri käytäntö on ollut monen uuden alku. Ammatillinen koulutus on mekanismi, joka siirtää tieteellisen tiedon ammatillisiksi sovellutuksiksi. Schönin mukaan kuitenkin tällä hetkellä vallitsee melkoi-

(sivulta 33)

Mietinnöstä ei löydy eväitä eri organisaatioissa avointa korkeakouluopetusta saavien tasa-arvoistamiseen. Tavoitteeksi olisi asetettava, että kaikilla aikuisopiskelijoilla maksut olisivat samansuuruisia tai mielummin niin, ettei niitä ole lainkaan. Se edellyttää valtiolta yhtäläistä tukea eri organisaatioille.

On selvä, ettei kesäyliopistotoimikunnan tehtävänä ollut täydennyskoulutuskeskusten toiminnan rukkaaminen. Kuitenkin toimikunnalta olisi odottanut selkeämpää linjausta niissä asioissa, jotka ovat kesäyliopistojen perinteistä ja edelleenkin keskeistä koulutusaluetta.

Valtiovallan intresseihin kuuluu, että korkeakoulujen varsinainen täydennyskoulutustehtävä tulee hoidetuksi eikä tuhlata resursseja tarpeettomasti sellaiseen toimintaan, joka muutenkin tulee hoidetuksi.
Tässä yhteydessä en tarkastele lähemmin toimikunnan näkemyksiä kesäyliopistojen ammatillisesta täydennyskoulutuksesta, kielikursseista, lukiolaiskursseista ja muusta opetuksesta. Yleisesti todettakoon, että niiltä osin mietintöön voi olla tyytyväisempi kuin avoimen korkeakouluopetuksen osalta. Kokonaisuutena toimikunnan työ tukee kesäyliopistojen toimintaedellytyksiä ja selkeyttää nıden asemaa koulutusjärjestelmässä. 
nen kuilu tieteellisen tiedon ja ammatillisen käytännön välillä. Schön ei hyväksy toimivana jakoa perustietoon, soveltavaan tietoon ja ammattikäytäntöön. Tämä jako on monen teknis-rationaalisesti rakennetun koulutusohjelman perusta. Schön ei halua hylätä teoreettista perustietoa. Teoreettisen tiedon käytännön yläpuolelle asettava näkökulma on vain liian yksipuolinen, jopa lähtökohtana virheellinen. Teorian ja käytännön vuorovaikutus tulisi koulutusohjelmissa ottaa uudelleen pohdittavaksi. Nykyisessä koulutusjärjestelmässä näkyvä teorian ja käytännön dualistisuus tulisi purkaa.

Schönin mukaan viime vuosina on yhä enemmän vahvistunut käsitys siitä, että tutkijoilla, joiden oletetaan tuottavan tietoa professionaalisen koulutuksen perustaksi, on yhä vähemmän sanottavaa käytännölle. Tieteellinen tutkimus on yhä enemmän irronnut ammattikäytännön todellisuudesta. Teorian ja käytännön kuilu näyttää vain syvenevän. Eri ammattiryhmien koulutuksessa ongelma on tiedostettu. Ratkaisuksi on esitetty erilaisia vaihtoehtoja. Esim. lääketieteen koulutuksessa on kiinnitetty huomiota tietoperustan yhä nopeampaan muuttumiseen, pyritty jäsentämään tietoperustaa uudelleen tai integroimaan perustietoa uudella tavalla. Joissakin koulutusohjelmissa on perustiedon sijaan pyritty kiinnittämään huomiota ammattikäytännön palvelutehtäviin ja lisätty koulutusohjelmiin esim. asiakassuhdekoulutusta. Ongelmaksi Schön kuitenkin näkee kokonaisuudessaan nykyisen lähestymistavan. Se ei ole korjattavissa yksittäisillä uudistuksilla. Koulutusohjelmien uudistaminen kaipaa lähtökohdakseen asiantuntijatyön käytännön epistemologian tutkimista.

\section{Taitava ammattikäytäntö - mitä se on}

Schön esittää, että teknis-rationaalisen asiantuntijakäsityksen mukaan on kahdenlaista asiantuntijatoimintaa. Toinen koostuu rutiinimaisista ratkaisuista, joissa voidaan soveltaa olemassaolevaa tietoperustaa. Nämä tilanteet voidaan myöhemmin korvata esim. asiantuntijajärjestelmillä. Toiset tilanteet ovat outoja, erikoisia, ainutkertai- sia ja arvoiltaan usein ristiriitaisia. Näihin tilanteisiin pitää kehittää uusia lähestymismalleja, jotka kuitenkin kaikki perustuvat yksiselitteisiin faktoihin. Kun ammatillinen tieto nähdään valmiina lähestymistapoina ja faktoina, ne voidaan kehittää ammattikäytännöstä irrallisina ja opettaa teknis-tyyppisen, tietoa välittävän koulutuksen avulla. Schönin mukaan tämä ei ratkaise tiedon ja käytännön välistä ongelmaa.

Schönin mukaan tärkeä tapa lähestyä asiantuntijatyön käytäntöä on eritellä taitavan ammattilaisen työtä. Mitä on taitava ammattilaisuus? Kysymys ei yleensä ole siitä, että henkilöllä olisi määrällisesti enemmän tietoa kuin kollegoillaan. Hänellä on jotain muuta: lahjakkuutta, intuitioita, ymmärrystä tai "taiteellisuutta" (artistry). Kysymys ei ole Schönin mukaan yksiselitteinen ja sitä on hyvin vähän tutkittu.

Hyvän asiantuntijakäytännön perustaksi Schön tuo jo edellisestä kirjastaan tutun reflektoivan toiminnan. Reflektoivan toiminnan kuvaus tapahtuu vertaamalla sitä teknis-rationaalisen asiantuntijatyöhön. Kun teknis-rationaalinen asiantuntija ottaa tavoitteet annettuna ja on vain tietoja käyttävä teknikko, reflektoiva asiantuntija rajaa ongelmaa uudelleen ratkaisun edetessä, muotoilee tilannetta uudelleen. Reflektointi on "kokeilua" (experimenting), jatkuvaa uudelleen rajausta, tilanteen kanssa "keskustelua", oman toiminnan tietoiseksi tekemistä sekä erilaisten ongelmien ja tilanteiden tietoista vertaamista. Tilanne pyritään ymmärtämään ennenkaikkea muuttamalla sitä.

\section{Reflektoivan ammattikäytän- nön oppiminen}

Reflektoivan ammattikäytännön oppiminen perinteisen luentomuotoisen opetuksen avulla on Schönin mielestä mahdotonta. Vaikka opettaja kuinka kertoisi omasta tavastaan toimia (esim. arkkitehtimäinen ajattelu) ei sillä ole vaikutusta opiskelijan todelliselle oppimiselle. Millainen on prosessi, jossa ihminen todella oppii jotain? Tämä prosessi sisältää enemmän kysymyksiä kuin valmiita vastauksia, vähintään yhtä paljon kiinnostusta siihen, mitä emme tiedä kuin siihen mitä tiedämme.

Oppimisen voi tehdä vain itse. Se vaatii ennen kaikkea omaehtoisen toiminnan ja oman aktiivisuuden suurta panosta opetuksessa. Schön nojautuukin tässä tekemällä oppimisen (learning by doing) perinteeseen. Hän on valmis hylkäämään kaiken erillisiin kursseihin ja luennointiin perustuvan opetuksen ja esittää sen sijaan studiomuotoista, case-tapauksiin ja tehtäviin perustuvia opetusmuotoja. Näin voidaan varmistaa reflektoivan ammattikäytännön oppimisen tärkeimmät piirteet.

\section{Asiantuntijatyön esimerkit}

Kirjassa Schön käyttää konkreettisina esimerkkeinä arkkitehdin työn oppimista (sama esimerkki kuin edellisessä kirjassa), musiikin opetusta, psykoanalyysin oppimista sekä vuorovaikutustaitojen oppimista (sama esimerkki kuin Argyriksen, 1985 teoksessa Action Science). Kussakin esimerkissä analysoidaan kyseistä työtä. Tässä Schön joutuukin erääseen koko kirjan keskeisimmistä ongelmista. Hänellä ei ole asiantuntijatyön analyysivälinettä. Hän erittelee esim. suunnittelutyön ja psykoanalyysin erilaisuutta vertaamalla töitä keskenään ja kuvaamalla niiden eroja esim. siten, että psykoterapiassa toisin kuin suunnittelussa tunkeudutaan ihmisen sisäiseen maailmaan. Musiikin opetuksen esimerkit ovat ongelmallisia ainakin sellaiselle, jolle musiikkitermien ja nuottien lukeminen ei ole itsestään selvää. Reflektoiva käytäntö konsultointitaidoissa kutistui jo edellä mainitussa Argyriksen teoksessa esitettyjen vuorovaikutusmallien oppimisen vertailuun.

\section{Reflektoivan työkäytännön op- pimisen ja opetuksen ongel- mat}

Schön pitää tärkeänä asiantuntijakoulutuksen kehittämistä edellä esitettyjen ajatusten mukaisesti, koska se on ainoa tapa luoda silta tutkimuksen ja ammattikäytännön välille. Monenlaisia ongelmia on edessä. Miten korkea-asteinen ammatillinen koulutus kokonaisuutena järjestetään? Koulutuksen uu- 
distuminen ei voi tapahtua vain opetussuunnitelmissa vaan se edellyttää koko yliopisto-opetuksen kulttuurin uudistumista. Tämänhetkinen yliopistojen todellisuus on Schönin mukaan jakautunut tieteenalakohtaisesti. Kukin on kiinnostunut vain omista, ainekohtaisista kursseistaan ja varjelee tarkasti omaa reviiriään. Yksilöllisyys ja kilpailu ovat yliopistojen todellisuutta, ei yhteistyö. Reflektoivan käytännön edellytyksenä olisi:

— tiedon ja käytännön suhteen uusi tarkastelu

- opetusohjelmien rakentaminen pois erillisistä kursseista, joihin opiskelijat vain osallistuvat

- koko opiskelukäytännön uusi traditio

- toisenlainen tutkimuksellinen lähestyminen.

Schön tuo esiin myös joitain ongelmia, joita asiantuntijakoulutuksessa on tunnistettu jo kauan, mutta joille ei käytännössä ole tapahtunut mitään. Yksi näistä on $\mathrm{mm}$. humaanimpien insinöörien tuottaminen, josta on puhuttu jo viimeiset 20 vuotta. Insinöörien koulutusohjelmissa ei kuitenkaan ole tapahtunut merkittäviä muutoksia.

Teoksen lopussa Schön kuvaa konkreettisesti Master of City Planning Program'in kehityksen 1970luvun alusta tähän päivään. Viime vuosikymmenen alussa yhteiskunnallinen tiedostaminen toi koulutusohjelmaan paljon uutta yhteiskunnallista ainesta, joka pian muuttui lukuisaksi määräksi irrallisia kursseja. Oli paljon valinnanvaraa, ja ongelmaksi tuli, että opiskelijat valitsivat vain pakolliset. 1970luvun lopussa opetusta ryhdyttiin koordinoimaan ja integroimaan, 1980-luvun alussa pohtimaan ajattelun opettamista teknisten taitojen sijaan ja 1983 ryhdyttiin opetuksen erillisiä saarekkeita purkamaan studio-opetuksen keinoin.

\section{Schönin tarkastelun rajoituksia}

Schön jatkaa teoksessaan jo aiemmin aloittamaansa jälkipositivistisen tieteenkäsityksen aikaansaaman asiantuntijatyön ja sen koulutuksen kritiikkiä. Hän painottaa koko ajan käytännön epistemologian merkitystä, mutta ei mielestäni kuitenkaan hylkää tiedettä ja teoriaa kokonaan. Hän esittää vain, että itsestään selvänä pidet- tyä suuntaa teoriasta käytäntöön tulisi tarkastella myös toisinpäin. Schönin teos tuo paljon mielenkiintoisia kysymyksiä, ajatuksia ja konkreettisia ratkaisuja, joista keskustelu olisi hyödyllistä myös suomalaisessa korkeakouluopetuksessa. Paljon avoimia kysymyksiä kuitenkin jäi.

Asiantuntijatyön analysointiongelma

Schöniltä puuttuvat asiantuntijatyön analyysin välineet. Asiantuntijatöiden kuvaus tapahtui vertaamalla esimerkkejä toisiinsa, toinen työ oli joissain piirteissään samanlaista, joissain erilaista kuin toinen. Vielä ongelmallisemmaksi asiantuntijatyön analyysi on suhteessa yhteiskunnalliseen kehitykseen. Schön tuo kritiikissään esiin, että asiantuntijatyö ei vastaa yhteiskunnan kehitykseen. Esimerkeissä ei kuitenkaan ole lainkaan analysoitu niitä haasteita, joita yhteiskunta kyseiselle työlle asettaa. Hyvät yleiset periaatteet eivät tältä osin olleet löytäneet sisältöä, jota esim. arkkitehdin työssä jäi kovasti kaipaamaan.

Taitavan ammattilaisen työn perusta

Esimerkeissään Schön kuvaa ammattitaitoa ikäänkuin sisäsyntyisenä. Hyvä ammattitaito on taitavan työntekijän "artistry". Toiset eivät koskaan opi ajattelemaan kuin arkkitehti, vaikka muuten ovat älykkäitä. Vaikka Schön tuo esiin mielenkiintoisia puolia asiantuntijan ammattitaidosta hän ei edes pyri selittämään näitä, pikemminkin mystifioimaan niitä toteamalla, että ne eivät ole verbaalisesti kuvattavissa. Mielestäni edellisessä teoksessa oli menty pitemmälle "artistryn", "tacit knowledgen" tai "seeing-as" ja "knowing-as" erittelyssä.

\section{Yksilöllinen ammattitaito}

Schön pitää tärkeänä asiantuntijoiden yhteistyötä. Kuitenkin kaikki esimerkit ovat yksilöllistä ammattitaidon kehittämistä ja oppimista kehittyneemmän oppipoikajärjestelmän avulla. Perinteiseen oppipoika-ajatteluun verrattuna Schön korostaa oppimisen jatkuvaa, ohjaajan kanssa vuorovaikutuksessa tapahtuvaa tiedostamista. Kaikki esimerkit kuvaavat kuitenkin yksilöllistä ammattitaidon kehittämistä. Vain ohjaajan (coach) kanssa pyritään muodostamaan yhteinen rajaus (refraiming) opiskelutehtäviin.

Valmiin asiantuntijan ammattitaidon kehittyminen

Schön tuo kirjan alkuosassa esiin myös sen, että koulutusjärjestelmälle ei riitä, että opiskelijoista koulutetaan taitavia ammattilaisia. Taitavakin ammattilainen tarvitsee jatkuvaa koulutusta uudistaakseen työvälineistöään (repertoire) ja välttääkseen burn out -ilmiön. Kritiikki jää kuitenkin irralliseksi. Se ei myöhemmin konkretisoidu. Epäselväksi jää, tarkoittaako Schön ammattitaidon uusimisella vain työvälineistön määrällistä lisäämistä (ammattitaidon täydentämistä) vai myös laadullisesti uuden kehittämistä. Miten asiantuntijaksi kehittyminen liittyy työn yhteiskunnalliseen kehitykseen ja sen aiheuttamiin haasteisiin? Miten luodaan laadullisesti uutta ammattitaitoa? Sitä Schön ei tuo esiin. Oppiminen on hänelle olemassaolevan omaksumista, irrallisten tietojen ja taitojen sijalla on vain "taitava ammattikäytäntö".

Kirsti Launis 